\title{
POMEN PROMETA ZA LJUBLJANSKO MESTNO AGLOMERACIJO
}

\author{
Andrej Černe \\ Oddelek za geografijo, Filozofska fakulteta, Univerza v Ljubljani, \\ Aškerčeva 2, 1000 Ljubljana \\ e-mail: andrej.cerne@guest.arnes.si
}

\section{Izvleček}

Prispevek je namenjen analizi prometno-geografskega položaja Ljubljane v kontekstu V. in $\mathrm{X}$. evropskega prometnega koridorja. Prikazani so temeljni elementi integralnega prometnega sistema, ki se nanašajo predvsem na prostorski potek in strukturo prometnega omrežja ter prometne tokove in njihove vplive na spreminjanje vloge prometno-geografskih dejavnikov pri gospodarski, prostorski in funkcijski povezanosti Ljubljane in Ljubljanske urbane regije v širši medregionalni, regionalni in prostorski razvoj Slovenije.

Ključne besede: prometno omrežje, prometni tokovi, Ljubljanska mestna aglomeracija

\section{THE SIGNIFICANCE OF TRANSPORT FOR THE LJUBLJANA URBAN AGLOMERATION}

\begin{abstract}
The article is analysing transport-geographical position of Ljubljana in the context of the V. and X. European transport corridor. The article describes basic elements of integral and intermodal transport system according to the infrastructure network, traffic flows and their impact on the changing role of transport-geographical factors within the economic, spatial and functional linkage of Ljubljana and Ljubljana urban region in interregional, regional and spatial development of Slovenia.
\end{abstract}

Key words: transport network, traffic flows, urban agglomeration of Ljubljana 


\section{EVROPSKI KONTEKST}

Slovenija kot makrogravitacijsko zaledje Ljubljane je s prometno-geografskega vidika ozemlje, ki je namenjeno predvsem izboljšanju prehodnosti evropskega prometnega omrežja ter gradnji manjkajočih in posodabljanje obstoječih odsekov evropskih prometnih koridorjev z namenom doseganja največjih možnih gospodarskih in prostorskih integracijskih učinkov.

Za EU pomeni Slovenija v razvoju prometnega omrežja predvsem prehodno območje, ki naj bi z ustrezno razvito prometno infrastrukturo ustvarila primerne pogoje za povezovanje EU s pomembnejšimi urbanimi središči v jugovzhodni in vzhodni Evropi.

$\mathrm{Za}$ EU je sodelovanje ter širitev proti vzhodnoevropskim trgom enako pomembno kot širitev in poglabljanje gospodarskega ter drugega sodelovanja $\mathrm{z}$ državami jugovzhodne Evrope. Smeri prometnega povezovanja Slovenije z EU pa so različnega pomena. Najpomembnejša je »severna« smer proti Avstriji in Nemčiji, ki pomenita za Slovenijo prioritetna gospodarska trga. Hkrati je pomembno postopno premikanje razvojnih središč iz zahodnega v osrednji del EU, ki ga predstavlja Nemčija $\mathrm{z}$ vse bolj središčno vlogo Berlina kot evropske prestolnice. Druga najpomembnejša je »zahodna smer« proti Italiji, ki prav tako predstavlja zelo pomembno gospodarsko partnerico Slovenije. Prometne smeri proti »vzhodu« in proti »jugu« pa so dolgoročno zelo obetavne in perspektivne. Mednje sodi tudi Luka Koper, ki je izrazito mednarodnega in medcelinskega pomena (Gulič, 1999).

Čez ozemlje Slovenije poteka več mednarodno pomembnih smeri povezav, med njimi tudi dve od sedmih transkontinentalnih magistralk:

- v smeri severozahod-jugovzhod: London, Bruselj, Frankfurt, Muenchen, Salzburg, Beljak, Jesenice, Ljubljana, Zagreb, Beograd, Niš, Istambul oziroma Atene; Amsterdam, Frankfurt, Linz, Graz, Šentilj, Maribor, Ptuj, Zagreb, Reka oziroma Balkanski polotok;

- v smeri jugozahod-sverovzhod: Barcelona, Milano, Ljubljana, Maribor, Budimpešta, Kijev.

Potek V. in X. koridorja preko ozemlja Slovenije kaže, da imata svojo začetno in končno točko v Kopru in prometno križǐ̌če, središče v Ljubljani. EU in Slovenija povsem različno zaznavata in uporabljata $\mathrm{V}$. in $\mathrm{X}$. koridor $\mathrm{v}$ njunem prehodu preko slovenskega ozemlja.

Na ozemlju Slovenije se križata V. in X. evropski prometni koridor, ki tvorita dve pomembni razvojni osi Evrope. V. vzpostavlja južnoevropsko razvojno os (Sunbelt), ki povezuje države od Španije do Ukrajine. Na tem koridorju so najpomembnejša milijonska urbana središča in prometna vozlišča Barcelona, Milano, Zagreb, Budimpešta in Kijev. X. tvori eno od pomembnejših razvojnih osi v smeri sever-jug in povezuje države od Avstrije do Grčije in Turčije. Kot najpomembnejša urbana in prometna vozlišča na tem koridorju so milijonske metropole Muenchna, Dunaja, Zagreba, Beograda, Aten in Carigrada.

Na najpomembnejšem križišču obeh prometnih koridorjev se nahaja Ljubljana kot srednje veliko evropsko mesto z manj kot pol milijona prebivalcev. Zaradi sorazmerne majhnosti in njenega makroregionalnega in mikroregionalnega zaledja je Ljubljana prepoznana, kljub dejanskemu in potencialnemu prometnemu vozlišču zgolj kot prehodno območje. 
V nasprotju z EU pa je ozemlje Slovenije za sosednje države (Avstrija, Italija, Madžarska in Hrvaška) ne samo prehodno ozemlje, preko katerega se želijo prometno povezovati $\mathrm{z}$ evropskimi urbanimi regijami ter njihovimi gospodarskimi trgi, marveč tudi ciljno območje na katerem želijo razširiti gravitacijski vpliv pomembnih urbanih središč.

Prioritetna prometna smer Italije je usmerjena preko slovenskega ozemlja proti državam vzhodne in jugovzhodne Evrope. Prioritetna prometna smer Avstrije je Luka Koper ter $\mathrm{z}$ njo povezana kopna smer sever-jug, ki je $\mathrm{v}$ večji meri navezana tudi na slovenski gospodarski prostor. Tej smeri sledi usmeritev proti jugu, najmanjšo prioriteto pa ima zahodna smer proti Italiji, saj ima Avstrija z Italijo že kakovostne neposredne prometne povezave.

Tudi strateški interes Madžarske so usmerjeni proti koprskemu pristanišču, čeprav je druga usmeritev proti reškemu pristanišču prav tako osrednjega pomena.

Vzpostavljanje čim bolj neposrednih prometnih povezav Hrvaške, predvsem preko Zagreba s pomembnimi urbanimi središči EU v večji meri potekajo mimo Ljubljane: Zagreb-Reka-Trst, Zagreb-Maribor-Gradec-Dunaj-Berlin, Zagreb-Ljubljana-Beljak.

$\mathrm{Na}$ tej podlagi se je razvilo ožje prometno gravitacijsko območje Slovenije, ki vključuje: Madžarsko, Češko, Slovaško, Avstrijo in Nemčijo, širše prometno gravitacijsko območje pa še Poljsko, Romunijo, Rusijo, Beneluks, Francijo, Švico, Albanijo. S prometom čez Slovenijo so države kot so Hrvaška, BiH, Srbija in Črna Gora, Grčija, Turčija in Bolgarija povezujejo s srednjo in zahodno Evropo. Pristanišče Koper, katerega 20\% delež prometa predstavlja tranzitni promet dobrin, ima velik pomen v mednarodnem prometu in povezovanju držav različnih delov Evrope. Ozemlje Slovenije predstavlja pomembno križišče glavnih prometnih smeri med Avstrijo, Češko, Slovaško in Madžarsko ter med tremi srednjeevropskimi pristanišči: Trst, Reka, Koper.

Zaradi geografskega položaja je Slovenija neposredno povezana s prometnimi sistemi $\mathrm{EU}$, kar je tudi eno izmed vodil za oblikovanje strategije razvoja prometne infrastrukture.

\section{MEDREGIONALNI IN URBANI KONTEKST}

Ljubljana se razprostira na $274.99 \mathrm{~km} 2$, kjer živi 268.537 prebivalcev in je največje mesto in najpomembnejši gospodarsko središče Slovenije. Leži na prometnem križišču, ki ustvarja dobre pogoje za prometno povezanost Ljubljane $\mathrm{z}$ ostalimi pomembnejšimi slovenskimi regionalnimi središči, središči sosednjih držav ter drugimi evropskimi urbanimi središči. Načrtovano izboljšanje cestnega in železniškega omrežja bo še okrepilo osrednjo prometno lego Ljubljane. Povprečni čas poti od Ljubljane do drugih 12 regionalnih središč bo na načrtovanem cestnem omrežju s 46 minutami najnižji (Gulič, 1999).

Po podatkih o dnevnih migrantih, aktivnih prebivalcih, zaposlenih, aktivnih, zaposlenih $\mathrm{v}$ storitvenem sektorju, povprečnem dnevnem številu vozil ter o blagovnem prometu na železniških postajah je najvišje $\mathrm{v}$ hierarhiji med urbanimi središči Ljubljana, razen po obsegu blaga po železnici (Koper). Najpomembnejše letališče je Ljubljansko letališče, kjer se obseg blaga in potnikov v zadnjih letih hitro povečuje. V ozkem pasu okrog Slovenije je v radiu $150 \mathrm{~km}$ od letališča Ljubljane 6 mednarodnih letališč, ki prevzemajo slovenskim letališčem znaten del potnikov in blaga. 
Poselitev Ljubljane se širi na obrobje, predvsem na razvojne osi ob glavnih cestah. Najbolj tipičen proces je dekoncentracija mestnega središča in disperzna poselitev na obrobju mesta. Samo v petih letih se je v mestnem središču število prebivalcev zmanjšalo za 4 \%.

Že prvi celoviti urbanistični dokument Ljubljane po II. vojni, Generalni urbanistični plan razvoja Ljubljane iz 1969. leta je predvidel razvoj mesta ob razvojnih krakih, katerih nosilke razvoja naj bi bile glavne mestne vpadnice. Kraki so bili predvideni za pozidavo v približno 400 m širokem pasu. Največjo pozornost je GUP namenil kraku ob Dunajski cesti, ob kateri je bila predvidena širitev središča mesta proti severu. Drugi dokument, Dolgoročni plan občin in mesta Ljubljane 1986 - 2000 (Prostorska zasnova, 2002) pa je že predvideval tudi gradnjo mestne železnice kot tudi nove trase železnice in druge infrastrukture zaradi reševanja perečih problemov mestnega in primestnega prometa.

V Nacionalnem programu razvoja Slovenske železniške infrastrukture (25. oktober 1995, UL RS 13, 1996) je predvideno:

- da se bodo prometni tokovi medsebojno združevali in povezovali na tako imenovanih prestopnih točkah - prometnih vozliščih. Na ta način naj bi bilo omogočeno povezovanje vseh vrst javnega in individualnega prometa, in sicer predvsem tako, da naj bi se v teh točkah združevali v integralno celoto železniški, avtobusni, letalski in pomorski sistemi ter individualni motorni, kolesarski in peš promet. Primarne prestopne točke naj bi omogočale prestop med različnimi železniškimi podsistemi, med železniškim in avtobusnim sistemom, kakor tudi med letalskim in pomorskim sistemom ter med sistemi javnega prometa na republiški in regionalni ravni. Sekundarne prestopne točke pa naj bi omogočale prestop med železniškim in avtobusnim sistemom ter kolesarskim prometom na lokalni (občinski) ravni.

Na podlagi tega so bili predvideni na območju Ljubljanske urbane regije: gradnja drugega tira na odseku Ljubljana-Jesenice, gradnja ljubljanskega železniškega vozlišča in gradnja potniške postaje Ljubljana.

Dolgoročni družbeni plan SR Slovenije za obdobje od leta 1986 - 2000 je bil sprejet leta 1986 in je z mnogimi popravki še danes veljaven dokument prostorskega razvoja Slovenije. Ta predvideva na območju Ljubljanske urbane regije:

- gradnjo drugega tira na magistralni smeri Ljubljana-Jesenice in pripravo hitre proge na tem odseku;

- $\quad$ gradnjo hitre proge Ljubljana-Dobova, vključno z obvozno progo v vozlišču Ljubljana s priključki;

- $\quad$ posodobitev vozlišča Ljubljana, Jesenice, Sežana, Divača, Maribor, Celje in Novo mesto;

- $\quad$ elektrificiranje okoli $275 \mathrm{~km}$ prog, povečanje dopustne obremenitve prog, posodabljan-je signalnovarnostnih in telekomunikacijskih naprav ter vlečne in prevozne zmoglji-vosti ter uvedba v mednarodni sistem povezano računalniško vodenje transportnega procesa;

- na trasah opuščenih prog naj bi bila možna taka raba zemljišč, ki bi dolgoročno omogočala gradnjo prog za primestni in medmestni železniški promet,

- $\quad$ uvajanje elektropogonskih nadzemnih vozil v večjih urbanih središčih, če bodo analize stroškov in koristi omogočale tako usmeritev;

- $\quad$ sistem in struktura prometnih tarif naj bi bil ekonomski instrument za družbeno racionalno izbiro prometnih sredstev (Kokalj, 2002). 
Pretežni del poselitve in delovnih mest v Ljubljani in širši regiji je skoncentriran v razvojnih koridorjih, kjer je potreba po prevozu ocenjena na 15.000 do 35.000 potnikov dnevno.

Tabela 1: Število prebivalcev in delovnih mest na območju razvojnih koridorjev Ljubljane leta 1998

Table 1: Number of inhabitants and working posts within the Ljubljana development corridors 1998

\begin{tabular}{|l|r|r|}
\hline Območja & $\begin{array}{r}\text { Mestno prebivalci } \\
\text { in delovna mesta }\end{array}$ & $\begin{array}{r}\text { Suburbano } \\
\text { prebivalstvo }\end{array}$ \\
\hline Ljubljana center & $11.833 / 20.318$ & \\
\hline Brod-Kranj & $61.127 / 9.701$ & 70.000 \\
\hline Črnuče-Kamnik & $41.885 / 10.585$ & 80.000 \\
\hline Zalog-Litija & $52.418 / 14.442$ & 20.000 \\
\hline Rudnik-Grosuplje & $19.672 / 2.221$ & 60.000 \\
\hline Vič-Vrhnika/Borovnica & $29.286 / 6.964$ & 40.000 \\
\hline
\end{tabular}

Vir: Public transport concept for city and region of Ljubljana. Phase $1 b-A, 1999$

Dnevne migracije v Ljubljano že presegajo številko 110.000 prebivalcev dnevno, sama motorizacija v mestu je narasla iz 335 na 448 vozil na 1.000 prebivalcev (Trajnostni razvoj MOL - strategija, 2001).

Tabela 2: Izbor prometnega sredstva v Ljubljani za leto 1994

Table 2: Modal split in Ljubljana 1994

\begin{tabular}{|l|c|}
\hline Prometna sredstva & Delež opravljenih potovanj \\
\hline Peš & 26,34 \\
\hline Kolo & 10,26 \\
\hline Moped, motor & 0,68 \\
\hline Osebni avto & 41,56 \\
\hline Javni promet & 21,16 \\
\hline
\end{tabular}

Vir: Integralna zasnova prometnega sistema, Elaborat 2, 2001

V prvi polovici 80 let so bili navezani na zaposlitev v ljubljanskih občinah predvsem prebivalci iz občin Domžale, Grosuplje, Vrhnika in Litija. Občini Kranj in Škofja Loka sta bili z Ljubljano manj povezani, saj so imeli prebivalci več možnosti za zaposlitev znotraj lastnih občin. Občine v južnem delu Ljubljanske regije so bile zaradi večjih razdalj in slabše dostopnosti manj navezane na zaposlitev v Ljubljani.

Gravitacijsko območje zaposlitve Ljubljane je obsegalo v smeri proti Gorenjski območje občine Ljubljana-Šiška do planskih con Kranj in Škofja Loka. Na zahodu je vključevalo Dobrovo, Polhov Gradec in Horjul, v smeri proti Vrhniki pa planske cone Brezovica, Presarje, Borovnico, predvsem pa Vrhnika, medtem ko je bil tok dnevnih delovnih migrantov iz Logatca in Rakeka še šibek. 
Tabela 3: Stevilo potovanj glede na prometno sredstvo in namen 1998

Table 3: Number of trips according to transport means and purposes 1998

\begin{tabular}{|l|r|r|r|r|r|r|}
\hline Namen & peš & kolo & motor & avtobus & vlak & avto \\
\hline Delo & 125 & 15 & 0 & 112 & 26 & 701 \\
\hline Šola & 167 & 13 & 3 & 258 & 27 & 36 \\
\hline Poslovno & 0 & 0 & 0 & 11 & 1 & 170 \\
\hline Ostalo & 4 & 52 & 3 & 106 & 12 & 881 \\
\hline
\end{tabular}

Vir: Bole, 2003

Slika 1: Zasnova prometnega omrě̌ja v Ljubljanski regiji

Figure 1: Scheme of transport network in Ljubljana region

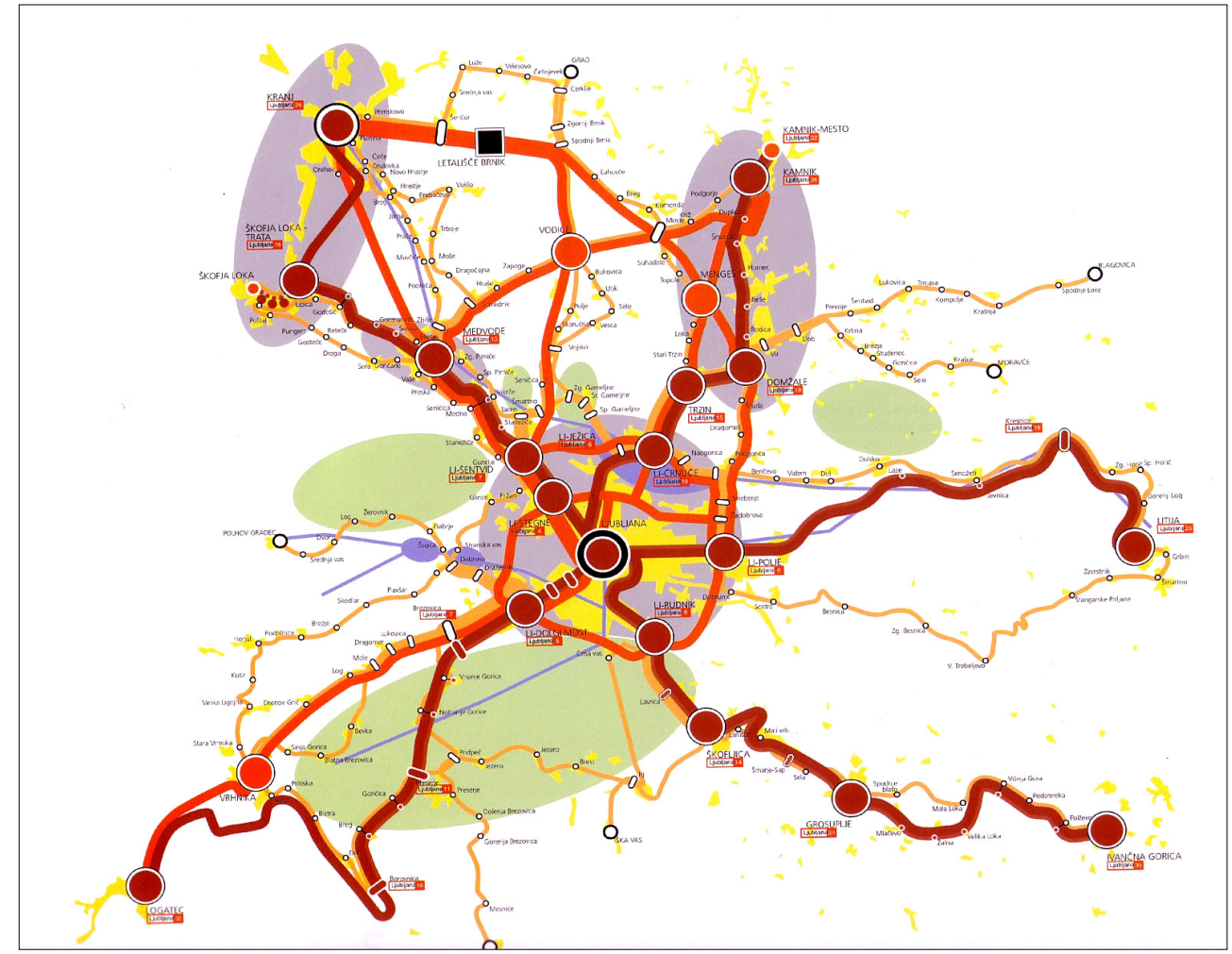

Vir: Prostorska zasnova. Prostorski plan Mestne občine Ljubljana. 2002

V južnem delu regije je zajemala območje dnevne delovne migracije v Ljubljano ostale planske cone občine Ljubljana-Vič-Rudnik in pretežni del Grosuplja, kjer je bila dobra dostopnost po dolenjski vpadnici. Tokovi dnevnih migrantov so segali do Ribnice in Kočevja.

Tok dnevnih delovnih migrantov iz litijske smeri je bil nekoliko šibkejši in je segal do planskih con Litija in Šmartno pri Litiji. V smeri proti Domžalam in Kamniku so se na delo 
v Ljubljano vozili predvsem prebivalci z dela občine Domžale iz planskih con Domžale, Mengeš in Radomlje, tokovi dnevnih delovnih migrantov pa so segali do Lukovice in Moravč, v občini Kamnik pa je bil obseg migrantov večji predvsem iz planske cone Kamnik.

Najbolj intenzivne medobčinske migracije v Ljubljano potekajo iz naslednjih občin: Borovnica, Brezovica, Cerklje na Gorenjskem, Dobrepolje, Dobrova-Polhov Gradec, Dol pri Ljubljani, Domžale, Gorenja vas-Poljane, Grosuplje, Horjul, Ig, Ivančna gorica, Kamnik, Komenda, Kranj, Litija, Logatec, Lukovica, Medvode, Mengeš, Moravče, Naklo, Preddvor, Šenčur, Škofja Loka, Škofljica, Trzin, Velike Lašče, Vodice, Vrhnika, Železniki, Žiri.

Od 171.461 zaposlenih v Ljubljanski mestni občini se jih je vozilo na delo iz Ljubljanske urbane regije 39.350. V absolutnem številu je bilo veliko dnevnih delovnih migrantov tudi iz nekaterih bližnjih gorenjskih občin (Kranj, Škofja Loka itd.), vendarle pa je tu delež zaposlenih v Ljubljani že nižji (Bole, 2003).

Tabela 4: Dnevno pripeljani potniki v Ljubljano v mestnem, mestnem cestnem in železniškem prometu leta 1998

Table 4: Daily passengers to Ljubljana in urban, suburban road and railroad traffic 1998

\begin{tabular}{|l|r|r|r|}
\hline Smeri & $\begin{array}{r}\text { Potniki pripeljani } \\
\text { v mestnim prometom }\end{array}$ & $\begin{array}{r}\text { Potniki pripeljani z } \\
\text { primestnim prometom }\end{array}$ & $\begin{array}{r}\text { Potniki pripeljani } \\
\text { z vlakom }\end{array}$ \\
\hline Kranj & 21.380 & 8.526 & 189 \\
\hline Kamnik-Domžale & 14.107 & 7.591 & 2.088 \\
\hline Litija & 20.921 & 232 & 2.382 \\
\hline Grosuplje & 7.064 & 3.697 & 1.259 \\
\hline Logatec & 11.084 & 4.447 & 974 \\
\hline
\end{tabular}

Tabela 5: Promet na območju Mestne občine Ljubljana 2002

Table 5: Traffic in municipality of Ljubljana 2002

\begin{tabular}{|l|r|}
\hline Vsa motorna vozila & 154.838 \\
\hline Osebna vozila & 127.969 \\
\hline Tovornjaki & 8.823 \\
\hline Avtobusi & 375 \\
\hline Število prebivalcev/osebni avto & 2,1 \\
\hline Prepeljani potniki z letali & 872.966 \\
\hline Prepeljani tovor z letali & $12.021 .000 \mathrm{~kg}$ \\
\hline Odpremljeni potniki po železnici & 2.192 .929 \\
\hline Prepeljani potniki z mestnim prometom & $94 \mathrm{mio}$ \\
\hline Število avtobusov mestnega prometa & 197 \\
\hline Število taksijev & 258 \\
\hline
\end{tabular}

Vir: Center za informatiko - Služba za mestno statistiko in analize, Mestna občina Ljubljana, 2004

Železniški javni potniški promet poteka na odsekih Ljubljana-Logatec, Ljubljana-Ivančna Gorica, Ljubljana-Litija, Ljubljana-Kamnik in Ljubljana-Medvode. 
Slika 2: Dnevno pripeljani potniki javnega potniškega prometa v Ljubljano

Figure 2: Daily passengers in public transport to Ljubljana

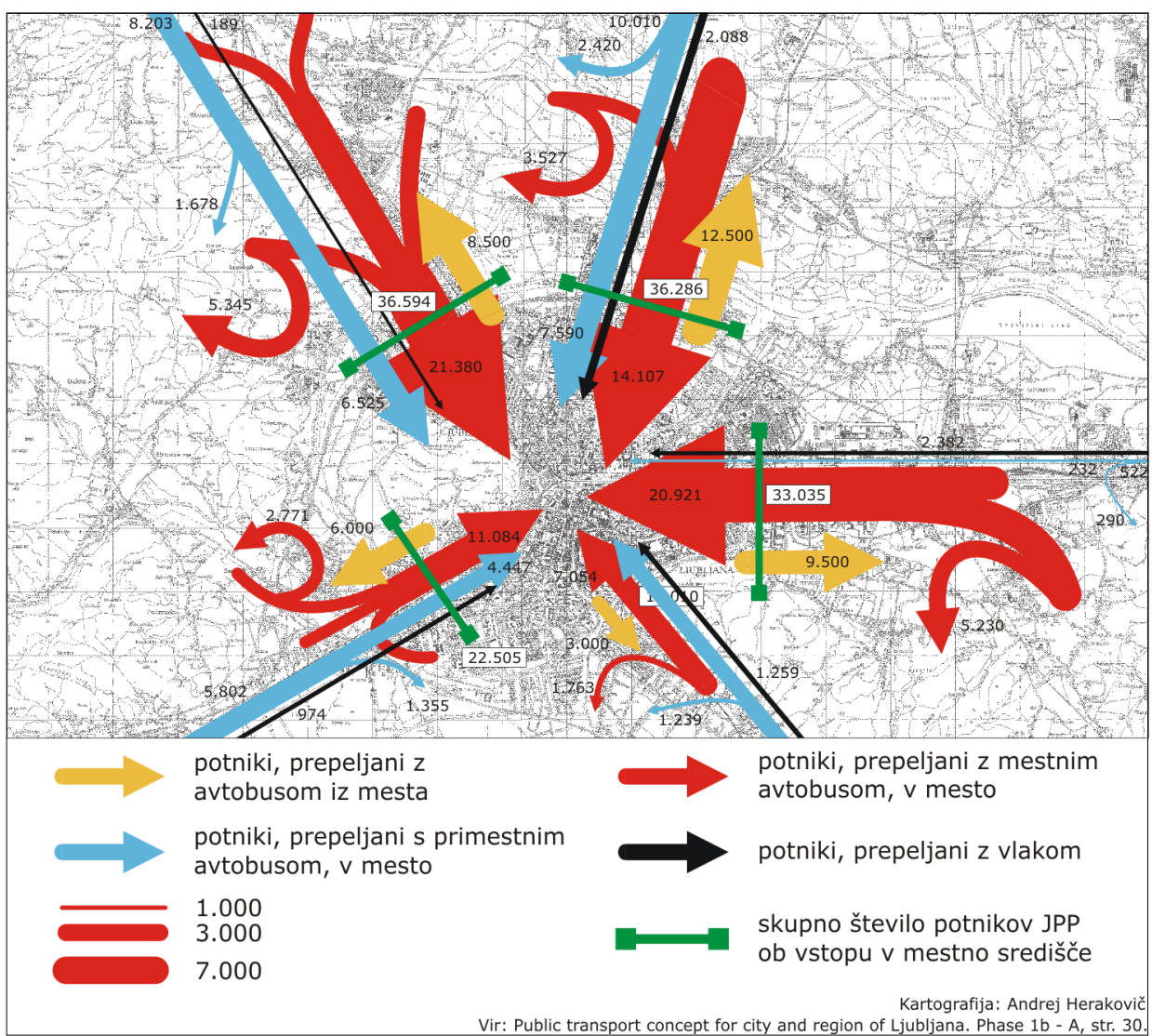

Vir: Public Transport Concept of City and Region of Ljubljana, 1999

Stanje in razvojne težnje na področju motorizacije, javnega potniškega prometa in cestne infrastrukture kažejo naslednje temeljne značilnosti:

- $\quad \mathrm{v}$ obdobju 1990-1996 je motoriziranost Ljubljane porasla za $25 \%$ in je v letu 1996 znašala 419 osebnih vozil na 1000 prebivalcev;

- $\quad$ rast voženj z osebnimi vozili in velik zaostanek pri posodabljanju javnega potniškega prometa se kaže $\mathrm{v}$ stanem upadanju števila prepeljanih potnikov v primestnem prometu; leta 1970 se je za uporabo javnega potniškega prometa odločalo $55 \%$ potnikov, leta $197750 \%$ in leta 1994 le še $34 \%$;

- eksterni stroški prometa, ki jih povzročajo prometni zastoji, prokomeren hrup, prometne nesreče, onesnaženost zraka in segrevanje ozračja, so ocenjeni na 5,2 do $14,7 \%$ slovenskega bruto domačega proizvoda;

- regionalni (železniški in avtobusni) in mestni promet so organizirani v ločenih gospodarskih organizacijah, ki si med seboj konkurirajo; 
- vlaki v glavnih razvojnih smereh dosegajo krajše potovalne čase, vendar imajo nizko pogostost voženj; železniške proge pa ne potekajo po najbolj gostih območjih poselitve; vlaki so slabo povezani z mestnim javnim prometom;

- mestna ulična mreža je zasičena s prometom, saj so nekateri cestni odseki dosegli obremenitve, ki so jih pred desetimi leti predvidevali za leto 2010;

- težnje kažejo na to, da bi javni potniški promet sodeloval v letu 2020 le še z 24 \% potovanj;

- zgostitve in prometni zastoji naj bi se razširili iz središča mesta na sosednja območja, vožnje hitrosti naj bi se znižale; zmanjšala naj bi se dostopnost središča;

- nadaljevanje teženj zahteva gradnjo dodatnih parkirišč; stroški celodnevnega parkiranja bi pospešili nadaljnje selitve prebivalcev in dejavnosti iz mestnega središča;

- močno se bo zmanjšalo število potnikov v javnem avtobusnem prometu.

Ob nadaljnjem razvoju osebnega prometa je pričakovati:

- $\quad$ prometne zastoje, ki se bodo razširili v mestno središče, kljub izgrajeni obvoznici;

- znižanje vozne hitrosti;

- slabša dostopnost do mestnega središča,

- pomanjkanje parkirnih prostorov v mestu; visoki stroški parkiranja;

- $\quad$ selitev dejavnosti na obrobje mesta zaradi boljše dostopnosti;

- nadaljnje zmanjševanje števila potnikov v javnem potniškem prometu;

- zviševanje potovalnega časa $\mathrm{z}$ avtobusi in povečevanje nekonkurenčnosti (Analiza, 2000, Trajnostni razvoj, 2001).

Za reševanje omenjenih problemov je bila v letu 2002 pripravljena Prostorska zasnova kot predhodno konceptualno gradivo za podrobnejši formalni dokument Prostorskega plana Mestne občine Ljubljana. Le-ta opredeljuje Koncept razvoja prometne infrastrukture, in sicer elemente koncepta, ki se nanaša predvsem na opredeljevanje prometne regije s središči, prometne povezave in smeri povezav, prometna vozlišča ter prometne terminale.

Pogoj za učinkovito delovanje urbanega sistema Ljubljanske urbane regije naj bi bila hitra medsebojna dostopnost vseh urbanih središč predvsem z javnim potniškim prometom, in sicer na podlagi zasnove tako imenovanega regionalnega sistema javnega potniškega prometa. Pomembni točki prestopa iz regionalnega na mednarodni prometni sistem naj bi bili železniška postaja Ljubljane, s prestopom na hitro evropsko železnico in letališče Brnik $\mathrm{z}$ letalskim prometom.

Regionalni sistem naj bi temeljil na ločevanju hitrih povezav od celovitega pokrivanja regije. Predvidene so tri vrste povezav: hitre linije, napajalne linije in mestne linije. Vse tri naj bi tvorile enoten regijski sistem javnega potniškega prometa in se naj bi medsebojno dopolnjevale. Moderni in konkurenčni tirni sistem javnega potniškega prometa $\mathrm{v}$ Ljubljanski urbani regiji naj bi vrnil regiji hierarhično strukturo in koncentriran prostorski razvoj in jo rešil številnih prometnih in prostorskih težav ter okrepil vlogo drugih središč v regiji. Hkrati pa bi okrepil konkurenčnost Ljubljane in njenega zaledja $\mathrm{v}$ širšem srednjeevropskem prostoru (Plevnik, 2002).

Hrbtenico prometnega sistema naj bi tvorile hitre linije, ki naj bi povezovale med seboj posamezna prometna vozlišča. Hitre linije naj bi potekale po temeljnih razvojno-pro- 
metnih oseh z najgostejšo poselitvijo in naj bi se ustavljale zgolj v prometnih vozliščih. Omogočale naj bi čim boljšo dostopnost med skrajnima točkama linij, in sicer v pol ure in manj. Tako imenovane napajalne linije naj bi v večji meri pokrivale manj gosto naseljena območja med vozlišči in okoli njih. V eni ali več točkah naj bi se napajalne linije priključevale na vozlišča, kjer naj bi bilo možno presedati na hitre in mestne linije. Mestne linije pa naj bi vzpostavljale omrežje pet minutne peš dostopnosti do javnega potniškega prometa $\mathrm{v}$ strnjenih urbanih območjih.

\section{Literatura in viri}

Analiza razvojnih možnosti prometne infrastrukture v prostoru. 2000, Strokovne podlage Ministrastva za promet R Slovenije. /http://www.sigov.si/mpz/2kabinet/1k.html.

Bole, D., 2003, Javni potniški promet in raba zemljišč v Ljubljani. Diplomsko delo, Oddelek za geografijo, Filozofska fakulteta, Univerza v Ljubljani, Ljubljana.

Černe, A., 2002, Javni potniški promet kot izraz gravitacijske noči Ljubljane. Geografija Ljubljane, Oddelek za geografijo, Filozofska fakulteta, Univerza v Ljubljani, Ljubljana, str. 191-212.

Gulič, A., Plevnik, A., 1999, Zasnova prometne infrastrukture v prostorskem planu Republike Slovenije. Zaključno poročilo projekta, Urbanistični inštitut Republike Slovenije, Ljubljana.

Integralna zasnova prometnega sistema. (2001) Elaborat 2, Ljubljanski urbanistični zavod, Ljubljana.

Koklaj, N., 2002, Regionalni tirni promet in poselitev v Ljubljanski urbani regiji. Diplomsko delo, Oddelek za geografijo, Filozofska fakulteta, Univerza v Ljubljani, Ljubljana.

Plevnik, A., 2002, Povezanost fizične zgradbe mest in prometa v mestih v Sloveniji. Doktorska disertacija, Oddelek za geografijo, Filozofska fakulteta, Univerza v Ljubljani, Ljubljana.

Prostorska zasnova. Prostorski plan Mestne občine Ljubljana. 2002, Mestna občina Ljubljana, Oddelek za urbanizem, Ljubljana.

Public Transport Concept of City and Region of Ljubljana. 1999, Phase 1b-A, Trnsport Technologie-Consult Karlsruhe, Karlsruhe, Ljubljana.

Trajnostni razvoj mestne občine Ljubljana - strategija. 2001, mestna občina Ljubljana, Oddelek za urbanizem, Ljubljana.

\section{THE SIGNIFICANCE OF TRANSPORT FOR THE LJUBLJANA URBAN AGLOMERATION}

\section{Summary}

Slovenia is directly connected with the transport systems of EU because of its geographical position and its infrastructural development strategy. Ljubljana as an middle big European 
city, with less than half a million of inhabitants is situated on the one of the most important transport junction of the V. and X. European transport corridor.

According to the transport geographical position the narrow transport gravitation area of Slovenia was developed. It comprises Hungary, Czech Republic, Slovakia, Austria and Germany. The extended transport gravitation area comprises Poland, Rumania, Russia, Benelux, France, Switzerland and Albania, The states as Croatia, Bosnia and Herzegovina. Montenegro, Greece, Turkey and Bulgaria are connected with transportation across Slovenia with Central and West Europe. Koper, with $20 \%$ of transit transport flows has an important role in this transport connection. The territory of Slovenia is an important centre of transport directions between Austria, Czech Republic, Slovakia, Hungary and three central European seaports: Trieste, Rieka and Koper.

The central geographical position gives Ljubljana very good conditions for its transport connectedness with Slovenian urban centres, centres of neighbouring countries and other European urban centres. Ljubljana is according to the daily migration, active population, and employed, active population in the tertiary activities, average transport flows and railway goods traffic the most important transport centre in Slovenia. It has also the most important airport in Slovenia. This is one of the reasons that daily migrations to Ljubljana already exceeded 110.000 commuters. The degree of motorisation increased from 335 to 448 vehicles per 1.000 inhabitants. Most of the urban development and working posts are concentrated in extended urban area of Ljubljana, within the four main development and transport corridors. 